\begin{tabular}{|c|c|}
\hline \multirow{3}{*}{ 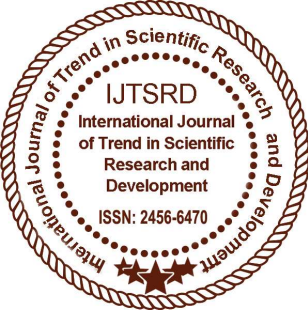 } & $\begin{array}{l}\text { International Journal of Trend in Scientific } \\
\text { Research and Development (IJTSRD) }\end{array}$ \\
\hline & International Open Access Journal \\
\hline & ISSN No: 2456 - 6470 | www.ijtsrd.com | Volume - 2 | Issue - 4 \\
\hline
\end{tabular}

\title{
Impact of Mahatma Gandhi National Rural Employment Guarantee Act (MGNREGA) on Unemployment and Village Economy
}

\section{Mohd Ashraf Mir}

Research Scholar, SOS in Political

Science \& Public Administration,

Jiwaji University, Gwalior

SC MLB College of Excellence, Gwalior

\author{
Suheel Azad \\ Research Scholar, SOS in \\ Commerce, SC MLB College of \\ Excellence Gwalior, Jiwaji \\ University, Gwalior
}

\author{
Dr. Vibha Doorwar \\ Associate Professor, MLB College \\ of Excellence Gwalior, Jiwaji \\ University, Gwalior
}

\section{ABSTRACT}

Eradicating Extreme Poverty and Hunger is the first and the primary concern of Millennium Development Goals (MDGs) . The primary consideration to trigger development should be to maximize work opportunities for the unemployed and under employed. A multifaceted developmental strategy has been adopted to address the needs of the poor by ensuring their basic rights and to promote economic growth. To fight unemployment, poverty and enhance livelihood security more effectively with multiplier effect on Social Capital formation, Physical Capital, Ecological Synergies, Strengthen Democratic Process and ensure Sustainable Development a new wage employment programme namely National Rural Employment Guarantee Act (NREGA) was formulated in 2005 and implemented in all the states and union territories of India in phased manner from February 2006 .With its legal frame work and rights based approach Mahatma Gandhi National Rural Employment Guarantee Act (MGNREGA) provides 100 days of guaranteed to every rural house hold whose adult members volunteer to do unskilled manual work with in a financial year . Some 25.15 crore workers under 7.08 crore job cards are registered under the scheme and 2449.25 crore person days have been generated with total expenditure of 425979.42 crore from inception of the scheme (22006 to $19-11-2017$ ) by providing employment to unemployed unskilled manual workers of rural India .There are several flagship programmes viz Bharat Nirman, Pradhan Mantari Gram Sadak Yojna,
Pradhan Mantari Awas Yojna, National Health Mission, Swatch Bharat Mission etc, in spite of all these programmes there are several gaps which MGNREGA can fill and also supplement these programmes under convergence module. Not much research work has been done on the current theme , hence this descriptive cum evaluative study seems to be due therefore conducted under this research paper.

Keywords: MGNREGA, Social Capital ,Physical Capital, Ecological Synergies, Strengthen Democratic Process, Unskilled Manual Work

\section{Introduction:}

In the recent past, the Government has taken several steps to provide employment to the labour force. One of the significant efforts in this direction is the enactment of the Mahatma Gandhi National Rural Employment Guarantee Act, 2005 (MGNREGA). MGNREGA is an important step towards the realization of the right to work and to enhance the livelihood security of the households in the rural areas of the country. The scheme provides at least 100 days of guaranteed wage employment in every financial year to every household whose adult member volunteers to do unskilled manual work.

Unemployment continues to be the barrier for the poor to escape the poverty trap. The Act aims to provide a safety net to the poor and unemployed from the "Poverty that Kills". The auxiliary objective of 
MGNREGA is regeneration and augmentation of natural resource base thereby to address the growing concerns of food security with emphasis on water and soil conservation through increasing squeeze on water availability and new irrigable land for expanded crop production, facilitating dual cropping and crop diversity which in turn facilitates employment hence multiplier effect of MGNREGA. From the inception of MGNREGA the average daily wage rate has increased from Rs 75 (approximately $\$$ 1.66 ) to 179 ( approximately $3.96 \$$ in financial year 2017-18 at the national Level.

\section{Objectives:}

1. To analyse the impact of MGNREGA on rural unemployment.

2. To analyse the need for skilling of workers.

\section{Data Analysis and Interpretation:}

3. To analyse the impact of MGNREGA on Rural Economy.

4. To suggest measures to strengthen the programme

\section{Methodology:}

Data has been collected from the secondary sources and interview method has also been put to practice.

\section{Universe of the study:}

Although the study gives over all status of employment generation at national level but comparative analysis had been made in respect of district pulwama block Keller and shadimarg of $\mathrm{J}$ \&K and District Gwalior Block Morar of Madhya Pradesh.

Table : 1 Facts about MGNREGA

\begin{tabular}{|c|c|}
\hline \multicolumn{2}{|l|}{ All India Status (as on 05-12-2017) } \\
\hline No. Of Districts & 685 \\
\hline No. Of Blocks $\rightrightarrows$ Or Irend in Sclentirl & 6865 \\
\hline No. Of GPs $\quad$ Research and & 262676 \\
\hline Total No. Of Job cards issued Development: & $12.58 \mathrm{Cr}$ \\
\hline Total No. Of workers & $25.25 \mathrm{Cr}$ \\
\hline Total No. Of Active Job Cards ISSN: 2456-6470 & $7.10 \mathrm{Cr}$ \\
\hline No. Of active workers & $11.04 \mathrm{cr}$ \\
\hline SC/ST data & \\
\hline SC workers against active workers $\%$ & $\begin{array}{ll}20.21 & \% \\
(16.16 \% \text { of population) } 2 * * & \\
\end{array}$ \\
\hline ST workers against active workers $\%$ & $\begin{array}{l}16.35 \% \\
(8.60 \% \text { of population })\end{array}$ \\
\hline
\end{tabular}

Source:

Ministry of Rural Development GOI official website; www.nrega.nic.in (Assessed on 1-12-2017)

Inference: SC s represent only 16.16 percent of population but comprise $20.21 \%$ of active workers and STs represent only 8.60 percent of population but comprise $16.35 \%$ of active workers hence the need is to enhance the guaranteed no. Of days under the scheme 
International Journal of Trend in Scientific Research and Development (IJTSRD) ISSN: 2456-6470

Table : 2 Details of Persondays Generated with averaged year wise wage rate.

\begin{tabular}{|l|l|l|l|l|l|}
\hline & $\begin{array}{l}\mathbf{2 0 1 7 - 1 8} \text { as } \\
\text { on } \\
(\mathbf{2 6 - 1 1 - 1 7 )}\end{array}$ & $\mathbf{2 0 1 6 - 1 7}$ & $\mathbf{2 0 1 5 - 1 6}$ & $\mathbf{2 0 1 4 - 1 5}$ & $\mathbf{2 0 1 3 - 1 4}$ \\
\hline Persondays Generated in Cr & 163.38 & 235.7584 & 235.1465 & 166.21 & 220.37 \\
\hline Average wage rater per days in Rs & 166.86 & 161.66 & 154.08 & 143.92 & 132.7 \\
\hline Wages paid in Crs & 31895.84 & 40789.17 & 30890.96 & 24187.26 & 26491.21 \\
\hline
\end{tabular}

Source:

1. Ministry of Rural Development GOI official website; www.nrega.nic.in (Assessed on 26-11-2017)

2**. Census 2011 GOI

\section{Inference:}

Some 1020.86 cr. Persondays have been generated only in last 56 months from April 2013 till 26-11-2017 with an average wage rate of Rs 151.76 per person perdays which clearly indicate that unemployed people have worked in their own gram Panchayat hence provided employment which in turn enhanced their economic status.

Table : 3 Details of Women Persondays

\begin{tabular}{|c|c|c|c|c|c|c|}
\hline & $\infty$ & 2017-18 as on & 2016-17 & 2015-16 & 2014-15 & 2013-14 \\
\hline & & $(26-11-17)$ & allon & & & \\
\hline Women persondays \% & Dis & 54.23 & 56.14 & 55.26 & 54.88 & 52.82 \\
\hline
\end{tabular}

\section{Source:}

1. Ministry of Rural Development GOI official website; www.nrega.nic.in (Assessed on 26-11-2017)

2. Census 2011 Population 121.01 cr Males 62.37 $\mathrm{Cr}$ females 58.64 $\mathrm{Cr}$ (Female 48.46\%)

Inference: Female workers out number the men workers hence need for their skilling hence an indication of security at work place by working within their own Gram Panchayat.

Table : 4 Details of Average persondays provided per house hold . ( all India )

\begin{tabular}{|l|l|l|l|l|l|}
\hline & 2017-18 as on (26-11-17) & 2016-17 & 2015-16 & 2014-15 & 2013-14 \\
\hline $\begin{array}{l}\text { Average persondays } \\
\text { provided per house } \\
\text { hold }\end{array}$ & 37.13 & 46.01 & 48.45 & 40.17 & 45.97 \\
\hline
\end{tabular}

Source:

Ministry of Rural Development GOI official website; www.nrega.nic.in (Assessed on 26-11-2017)

Inference : Average wage rate are on increase but still not compatible with market rates. 
TABLE : 5 Details of person days generated district Pulwama Block Shadimarg and Keller (Jammu \& Kashmir )

\begin{tabular}{|c|c|c|c|c|c|c|c|c|c|c|c|}
\hline \multirow[t]{2}{*}{ State } & \multirow[t]{2}{*}{ Distt. } & \multirow[t]{2}{*}{ Block } & \multirow[t]{2}{*}{ Panchayat } & \multirow{2}{*}{$\begin{array}{l}\text { No. Of } \\
\text { active } \\
\text { job } \\
\text { cards }\end{array}$} & \multicolumn{5}{|c|}{ Person days Generated year wise } & \multirow{2}{*}{$\begin{array}{l}\text { Total } \\
\text { Person } \\
\text { days } \\
\text { Generat } \\
\text { e }\end{array}$} & \multirow[b]{2}{*}{$\begin{array}{l}\text { Avr. Pd s } \\
\text { per year } \\
\text { per jC }\end{array}$} \\
\hline & & & & & $\begin{array}{l}2017- \\
18 \text { as } \\
\text { on } \\
(26- \\
11- \\
17)\end{array}$ & $\begin{array}{l}2016- \\
17\end{array}$ & $\begin{array}{l}2015- \\
16\end{array}$ & $\begin{array}{l}2014- \\
15\end{array}$ & $\begin{array}{l}2013- \\
14\end{array}$ & & \\
\hline $\mathrm{J} \& \mathrm{~K}$ & Pulwama & Shadimarg & Kalampora & 291 & 4459 & 6645 & 9841 & 8202 & 10076 & 39223 & 28.92 \\
\hline J\&K & Pulwama & Shadimarg & Nikas & 235 & 3316 & 4210 & 4672 & 1151 & 5006 & 18355 & 16.76 \\
\hline$J \& K$ & Pulwama & Shadimarg & Rajpora B & 187 & 9334 & $\begin{array}{l}1129 \\
4\end{array}$ & 11805 & 3424 & 7972 & 43829 & 50.30 \\
\hline$J \& K$ & Pulwama & Shadimarg & $\begin{array}{l}\text { Drabgam } \\
\text { A }\end{array}$ & 260 & 6144 & 3379 & $2963 \propto$ & 2246 & 3338 & 18070 & 14.91 \\
\hline$J \& K$ & Pulwama & Keller & $\begin{array}{l}\text { Sangerwan } \\
\text { i A }\end{array}$ & 434 & 412 & 1344 & 1931 & & 800 & 5432 & 2.69 \\
\hline$J \& K$ & Pulwama & Keller & $\begin{array}{l}\text { Sangerwan } \\
\text { i B }\end{array}$ & 283 ไa & 59 กล & 2348 & 25312 & 0 & 201 & 5139 & 3.90 \\
\hline Total & & & 8 & $\begin{array}{l}1690 \\
\text { Res }\end{array}$ & $\begin{array}{l}2372 \\
4 a r c\end{array}$ & $\begin{array}{l}2922 \\
0 \text { ar }\end{array}$ & d3743 & 15968 & 27393 & 130048 & 16.51 \\
\hline
\end{tabular}

Source:

Ministry of Rural Development GOI official website; www.nrega.nic.in (Assessed on 26-11-2017)

Inference : Halqa Sangerwani A and B are the Gram Panchayats dominated by SC population but average persondays per job card are negligible whereas at the national level SC active workers out number their population share hence a concern for the state of J\& K. And in case of other GPs the average persondays per Job card is below national average in all the years.(43.62 in last five years.)

ii. : Halqa Sangerwani A and B are the Gram Panchayats dominated by SC population but the number of persondays generated are the least in these two gram panchayats. On having face to face interaction with them, the researcher reached to the conclusion that the awareness level regarding the scheme is very low and being a far flung area lack of supervision has resulted in failure of the scheme in the said two Gps although topographicaly the scheme is having tremendous scope in the area. In rest of the GPs the schme has increased the employment opportunities and reduced migration rate.

iii. $130048 / 1690=76.96 / 4.66=16.51$ person days per House Hold per year 
International Journal of Trend in Scientific Research and Development (IJTSRD) ISSN: 2456-6470

Table : 6 District Gwalior Block Morar ( Madhya Pradesh) Average PDs per HH

\begin{tabular}{|c|c|c|c|c|c|c|c|c|c|c|c|}
\hline \multirow[b]{2}{*}{ State } & \multirow[b]{2}{*}{ Distt. } & \multirow[b]{2}{*}{ Block } & \multirow[b]{2}{*}{ Panchayat } & \multirow[b]{2}{*}{$\begin{array}{l}\text { No. Of } \\
\text { active job } \\
\text { cards }\end{array}$} & \multicolumn{5}{|c|}{ No. of Person days Generated } & \multirow[b]{2}{*}{$\begin{array}{l}\text { Total } \\
\text { Pds }\end{array}$} & \multirow[b]{2}{*}{$\begin{array}{ll}\text { Avr. } & \text { Pd } \\
\text { s p per } \\
\text { year per } \\
\text { jC }\end{array}$} \\
\hline & & & & & $\begin{array}{l}2017- \\
18 \text { as } \\
\text { on } \\
(26- \\
11-17)\end{array}$ & $\begin{array}{l}2016- \\
17\end{array}$ & $\begin{array}{l}2015- \\
16\end{array}$ & $\begin{array}{l}2014- \\
15\end{array}$ & $\begin{array}{l}2013- \\
14\end{array}$ & & \\
\hline MP & Gwalior & Morar & Ratwai & 71 & 3,085 & 7,279 & 5,111 & 13,912 & 5,642 & 35,029 & 105.87 \\
\hline MP & Gwalior & Morar & Bandholi & 135 & 5,139 & 5,403 & 7,117 & 1,529 & 1,402 & 20,590 & 32.73 \\
\hline MP & Gwalior & Morar & Rai & 123 & 5,184 & 3,533 & 6,782 & 9,859 & 3,076 & 28,434 & 49.61 \\
\hline MP & Gwalior & Morar & $\begin{array}{l}\text { Bhatpura } \\
\text { sani }\end{array}$ & & 1,777 & 1,338 & 456 & 1,049 & 1,176 & 5,796 & 12.31 \\
\hline MP & Gwalior & Morar & Barja & 113 & 3,007 & 2,139 & 4,111 & 1,112 & 3,544 & 13,913 & 26.42 \\
\hline MP & Gwalior & Morar & Sosa & $720^{\circ}$ & 1,561 & 2,199 & 5,553 & 3,026 & 4,241 & 16,580 & 49.42 \\
\hline & & & Total $\mathrm{C}$ & 615 & 19,753 & 21,891 & 29,130 & 30,487 & 19,081 & $1,20,342$ & 41.99 \\
\hline
\end{tabular}

Source:

Ministry of Rural Development GOI official website; www.nrega.nic.in (Assessed on 26-11-2017)

Inference : The average persondays per house hold is below national average in $50 \%$ of GPs in all the years.(43.62 in last five years.) but at the same time better than J\& K (2.5 timesApprox.)

Table : 7 District Pulwama Block Shadimarg \& Keller ( Jammu and Kashmir) (HHs completed 100 days)

\begin{tabular}{|c|c|c|c|c|c|c|c|c|c|c|c|}
\hline & & & 0,0 & & $\begin{array}{l}\text { No. o } \\
\text { days }\end{array}$ & Hous & holds & Compl & ted 100 & & \\
\hline $\begin{array}{l}\text { Stat } \\
\mathrm{e}\end{array}$ & Distt. & Block & Panchayat & $\begin{array}{l}\text { No. } \\
\text { Of } \\
\text { active } \\
\text { job } \\
\text { cards }\end{array}$ & $\begin{array}{l}2017 \\
-18 \\
\text { as on } \\
(26- \\
11- \\
17)\end{array}$ & $\begin{array}{l}2016 \\
-17\end{array}$ & $\begin{array}{l}2015 \\
-16\end{array}$ & $\begin{array}{l}2014 \\
-15\end{array}$ & $\begin{array}{l}2013- \\
14\end{array}$ & $\begin{array}{l}\text { Total } \\
\text { HH } \\
\text { complet } \\
\text { ed } 100 \\
\text { days in } \\
4.66 \\
\text { years }\end{array}$ & $\begin{array}{l}\text { Avr. HH } \\
\text { complet } \\
\text { ed } 100 \\
\text { days }\end{array}$ \\
\hline J\&K & $\begin{array}{l}\text { Pulwam } \\
\text { a }\end{array}$ & $\begin{array}{l}\text { Shadima } \\
\text { rg }\end{array}$ & $\begin{array}{l}\text { Kalampor } \\
\text { a }\end{array}$ & 291 & 1 & 0 & 3 & 14 & 16 & 34 & 0.12 \\
\hline $\mathrm{J} \& \mathrm{~K}$ & $\begin{array}{l}\text { Pulwam } \\
\text { a }\end{array}$ & $\begin{array}{l}\text { Shadima } \\
\text { rg }\end{array}$ & Nikas & 235 & 0 & 0 & 0 & 0 & 4 & 4 & 0.02 \\
\hline $\mathrm{J} \& \mathrm{~K}$ & $\begin{array}{l}\text { Pulwam } \\
\text { a }\end{array}$ & $\begin{array}{l}\text { Shadima } \\
\text { rg }\end{array}$ & Rajpora B & 187 & 19 & 2 & 3 & 3 & 4 & 31 & 0.17 \\
\hline $\mathrm{J} \& \mathrm{~K}$ & $\begin{array}{l}\text { Pulwam } \\
\text { a }\end{array}$ & $\begin{array}{l}\text { Shadima } \\
\text { rg }\end{array}$ & $\begin{array}{l}\text { Drabgam } \\
\text { A }\end{array}$ & 260 & 11 & 0 & 0 & 0 & 2 & 13 & 0.05 \\
\hline $\mathrm{J} \& \mathrm{~K}$ & $\begin{array}{l}\text { Pulwam } \\
\text { a }\end{array}$ & Keller & $\begin{array}{l}\text { Sangerwa } \\
\text { ni A }\end{array}$ & 434 & 0 & 0 & 0 & 0 & 0 & 0 & 0.00 \\
\hline J\&K & $\begin{array}{l}\text { Pulwam } \\
\text { a }\end{array}$ & Keller & $\begin{array}{l}\text { Sangerwa } \\
\text { ni B }\end{array}$ & 283 & 0 & 0 & 0 & 0 & 0 & 0 & 0.00 \\
\hline & & & Total & 1690 & 31 & 2 & 6 & 17 & 26 & 82 & 0.05 \\
\hline
\end{tabular}


Source:

1.Ministry of Rural Development GOI official website; www.nrega.nic.in (Assessed on 26-11-2017)

Table : 8 District Gwalior Block Morar (Madhya Pradesh) (HHs completed 100 days)

\begin{tabular}{|c|c|c|c|c|c|c|c|c|c|c|c|}
\hline & & & & & $\begin{array}{l}\text { No. o } \\
\text { days }\end{array}$ & Hous & holds & Comp & ed 100 & & \\
\hline $\begin{array}{l}\text { Stat } \\
\mathrm{e}\end{array}$ & Distt. & Block & Panchayat & $\begin{array}{l}\text { No. } \\
\text { Of } \\
\text { activ } \\
\text { e job } \\
\text { card } \\
\text { s }\end{array}$ & $\begin{array}{l}2017 \\
-18 \\
\text { as on } \\
(26- \\
11- \\
17)\end{array}$ & $\begin{array}{l}2016 \\
-17\end{array}$ & $\begin{array}{l}2015 \\
-16\end{array}$ & $\begin{array}{l}2014 \\
-15\end{array}$ & $\begin{array}{l}2013- \\
14\end{array}$ & $\begin{array}{l}\text { Total } \\
\text { HH } \\
\text { complet } \\
\text { ed } 100 \\
\text { days in } \\
4.66 \\
\text { years }\end{array}$ & $\begin{array}{l}\text { Avr. HH } \\
\text { complet } \\
\text { ed } 100 \\
\text { days }\end{array}$ \\
\hline $\mathrm{MP}$ & Gwalior & Morar & Ratwai & 71 & & & 2 & 103 & 5 & 111 & 1.56 \\
\hline MP & Gwalior & Morar & Bandholi & 135 & 0 & 1 & 3 & 2 & 0 & 6 & 0.04 \\
\hline MP & Gwalior & Morar & Rai & 123 & 1 & 0 & 13 & 36 & 5 & 55 & 0.45 \\
\hline MP & Gwalior & Morar & $\begin{array}{l}\text { Bhatpura } \\
\text { sani }\end{array}$ & 101 & 0 & 1 & 0 & 5 & 3 & 9 & 0.09 \\
\hline MP & Gwalior & Morar & Barja & $\begin{array}{l}113 \\
\text { Res }\end{array}$ & 0 & 0 & 9 & 0 & 1 & 10 & 0.09 \\
\hline $\mathrm{MP}$ & Gwalior & Morar & Sosa & $72 \mathrm{el}$ & 0 & 0 & 1 & 2 & 2 & 5 & 0.07 \\
\hline & & & Total & 615 & 1 & 3 & 28 & 148 & 16 & 196 & 0.32 \\
\hline
\end{tabular}

Source:

1.Ministry of Rural Development GOI official website; www.nrega.nic.in (Assessed on 26-11-2017)

Table :09 Consolidated delayed payment details

\begin{tabular}{|c|c|c|c|c|c|c|c|}
\hline \multicolumn{8}{|c|}{$\%$ Age of DELAYED PAYMENTS UNDER MGNREGA } \\
\hline S.No & State & 13-14 & 14-15 & 15-16 & 16-17 & 17-18 & Inference \\
\hline 1. & $\mathbf{J} \& \mathbf{K}$ & 78.75 & 90.66 & 88.35 & 95.97 & 85.45 & Delayed \\
\hline 2 & $\begin{array}{l}\text { MADHYA } \\
\text { PRADESH }\end{array}$ & 62.86 & 83.64 & 71.92 & 44.98 & 19.51 & $\begin{array}{l}\text { times higher in } \\
\mathrm{J} \& \mathrm{~K} \text { as }\end{array}$ \\
\hline 3. & India & 49.92 & 73.15 & 66.34 & 55.38 & 17.97 & $\begin{array}{l}\text { National level, } \\
\text { hence need to be } \\
\text { checked. }\end{array}$ \\
\hline
\end{tabular}


International Journal of Trend in Scientific Research and Development (IJTSRD) ISSN: 2456-6470

Table :10 Panchayats with no expenditure under MGNREGA

\begin{tabular}{|l|l|l|l|l|l|}
\hline \multicolumn{2}{|l}{ Panchayats with no expenditure under MGNREGA } & & GPS WITH NO & $\begin{array}{l}\text { \%age of GPs } \\
\text { with Nill } \\
\text { Exp. }\end{array}$ & $\begin{array}{l}\text { Role of } \\
\text { Supporting } \\
\text { Staff }\end{array}$ \\
\hline YEAR & STATE & Total GPs & EXPENDITURE & $17-12-2018$ \\
\hline $2013-14$ & India & 262714 & 27154 & 10.34 & \\
\hline $2014-15$ & India & 262714 & 39531 & 15.05 & \\
\hline $2015-16$ & India & 262714 & 39469 & 15.02 & \\
\hline $2016-17$ & India & 262714 & 19479 & 7.41 & \\
\hline $2017-18$ & India & 262714 & 16666 & 6.34 & \\
\hline
\end{tabular}

\section{SUGGESTIONS AND CONCLUSION:}

1. SC and ST workers out number their population share which indicates their willingness to work and unemployment scenario hence number of guaranteed days need to be increased in one hand and skilling initiatives to be taken in to other hand.

2. Women participation is higher than their male counterparts in percentage terms which indicated their willingness to work. Women need to be engaged as work site mates where the women workers out number men. It is equally true that almost $40 \%$ of the states/ UTs are lagging behind with regard to mandatory requirement of $33 \%$ participation of women workers. It is true that that MGNREGA reduced traditional gender wage discrimination.

3. Women feel secure to work under the scheme with in their Village and GPs but work site facilities be provided to them with inclusion free sanitation pads to women workers.

4. SC/ST and women workers in particular who work for more than 70 days in a year under the scheme be got insured under Aam Admi Beema Yojna and Medical claim Insurance by paying their premium by state exchequer from administrative expenses for next financial year subjected he/she will work for at least 70 days under the scheme in the ensuing financial year.

5. Delay is payment of wages need to be minimised by introduction of eFMS and providing internet connectivity in far flung areas .
6. In far flung areas the supervision and monitoring mechanism is very week hence least demand under the scheme although tremendous scope for the scheme which need to be strengthened.

7. Periodically enhancement in wages keeping cost of living and labour market rates of different states in to consideration.

8. Deduction amounting to due delayed compensation amount be made from the salary/ wages of the official responsible for delay in payment of wages to fix the responsibility.

9. Skilling of the workers to enhance their purchasing power and facilitate to come out of the vicious circle of manual labouring is the need of the hour.

\section{REFERENCES}

1) Rao,Srinivas.K and Mashushudan B.V(2013), Role of MGNREGA in Improving land Productivity, Centre for Budget and Policy Studies, Bangalore for Department of Rural Development, Government of Karnataka .

2) Deininger and Liu, 'Poverty impacts of Indian`s NREGS: Evidence from Andhra Pradesh`.

3) India: Ministry of Rural Development, Department of Rural Development <http: //nrega.nic.in/ NREGA_guidelinesEng.pdf>. Accessed September 26, 2017 and 26-11.2017

4) K, Booner,et al., "MGNREGA implementation: A Cross State Comparison. 
5) Ministry of Labour and Employment. Report of Fifth Annual Employment -Unemployment Survey $2015-16$ p.120

6) Annual Report of RBI published in 2013

7) Census of India 2011 ( online ) assessed 0n 20-122017

8) Ministry of Rural Development Govt. Of India MGNREGA Sameeksha; An Anthology of Research Studies on MGNREGA, 2005 (2006-12)

9) R.M. Sudarshan,' Examining India's Regional Employment Guarantee Act: Its impact and Women Participation'. New Delhi Institute of Social Studies trust (ISST), 2009.

10) India, Ministry of Rural Development. 2005. The National Rural Employment Guarantee Act 2005 (NREGA): Operational guidelines. New Delhi.

11) India Ministry of Rural Development, -The National Rural Employment Guarantee Act 2005 (MGNREGA): Operational guidelines 4rth Edition 2013

12) Master Circular 2016-17 issued by India Ministry of Rural Development

13) MGNREG Act 2005 Report to the People $-2^{\text {nd }}$ February 2013, Ministry of Rural Development, Department of Rural Development Government of India

14) A Hand Book Published by Rural Extension Centre Budgam J \& K 16-17 ( Training Wing of Rural Development Department Kashmir) 